\title{
Reports and Journals
}

The Launching of a New Ark: First Report of the World Wildlife Fund, edited by Peter Scott. Collins, 13s. 6d. post free from WWF, 2, Caxton Street, London, SWI.

Five years after it was thought of, and four years after it officially began, the World Wildlife Fund has produced its first report. It is over 200 pages long, handsomely produced (free) by Collins, well stocked with pictures and with much useful information-like the 50 pages listing rare mammals and birds. There are 40 pages about projeots already helped, and 30 more about approved projects awaiting funds. There is also much preamble-a blunt statement on conservation by Peter Scott (who edited the report) and an emotional one (better reading) by Elspeth Huxley. There are 14 pages giving a "blueprint" for setting up a National Appeal, and various other bits and pieces of rewarding matter. Where the report is weakest is in discussing its raison d'être-money.

Way back at the time of the Arusha Conference in September, 1961, and when WWF was being born, there was talk of $\mathfrak{f} 1$ million. There is still such talk, and this report states a target of $£ 1 \frac{1}{2}$ million every year. I personally wonder whether such financial enthusiasm, however much we wish them the money, leaves a taint of dissatisfaction if achievement falls too far behind. By the end of 1964 , after three years of existence, $£ 315,000$ had been given away internationally, $£ 57,000$ had been consumed nationally, and a further $£ 300,000$ had been given for conservation by third parties after prodding from the WWF, such as the Spanish Government producing $£ 137,000$ for the Marismas of the Guadalquivir. The Report points out that the money raised has "fallen short of the more optimistic estimates made before its formation."

The accounts and balance sheets, which incidentally, only go up to the end of 1963, are not notably clear. I agree this is common practice in reports, but I think the ritual should be more cogently resisted when the report deals with a fund's activities. In this instance, the type selected for the accounts is considerably smaller than elsewhere, a fact probably enforced by the confusion of using Swiss francs, sometimes on their own, sometimes coupled with pounds sterling, and with the occasional mention of US dollars and Spanish pesetas. All international grants mentioned in the text are given in f's and \$'s, but the order is irritatingly uneven.

So far, Britain, the United States, Switzerland, Holland, Germany and Austria have started National WWF Appeals, and in that order. Seven more countries are reportedly planning them. Let us hope that this wellwritten, clear (except for that cash), useful and attractive volume adds even more to the list, and makes all that talk of millions something of a reality.

ANTHONY SMITH.

\section{FOR REFERENCE}

A useful summary, country by country, of the main libraries, information bureaux, and other sources of scientific information is found in World Guide of Science Information and Documentation Services (UNESCO, 20s). In the UK, for instance, these are Aslib, the new National Lending Library for Science and Technology at Boston Spa in Yorkshire, and the Science Museum Library in South Kensington.

An echo of its imperial past qualifies the FPS, which started life as the Society for the Preservation of the Fauna of the Empire, to continue to appear in a useful work of reference, The Handbook of Commonwealth Organisations (Methuen, 30s), sandwiched somewhat incongruously between the British Association of the Experiment in International Living and the Meteorological Office. 